\title{
Ontogenic events and swimming behavior of larvae of the characid fish Salminus brasiliensis (Cuvier) (Characiformes, Characidae) under laboratory conditions
}

\author{
José Enemir dos Santos ${ }^{1}$ \\ Hugo Pereira Godinho ${ }^{1}$
}

\begin{abstract}
The larval ontogeny and swimming behavior of the characid fish Salminus brasiliensis (Cuvier, 1816) were studied under experimental laboratory conditions, from hatching to yolk absorption. At day 1, the larvae were transparent, with sparse dendrite chromatophores and a well-developed adhesive organ on the head. The retinal epithelial cells were initiating pigmentation. The branchial arches were at the initial phase of differentiation. The larvae were able to perform only vertical displacements and, when resting on the tank bottom, remained in lateral decumbency, in groups of 3 to 15 larvae. On day 2, the mouth was open, with conical teeth, and the digestive tube presented lumen and folded mucosa. The gaseous bladder and pectoral fins also were in differentiation. The larvae performed vertical and horizontal movements, adhered to the water surface by means of the adhesive organ or formed groups of three to six on the tank bottom. On day 3 , the adhesive organ turned dorsal, the retina was pigmented, the digestive tube mucosa showed goblet cells, and the yolk sac exhausted. The larvae were now scattering in the water column forming no groups on the bottom.
\end{abstract}

KEY WORDS. Salminus brasiliensis, larval ontogenic events, larval swimming behavior

Knowledge on larval development of freshwater teleost is limited (SOUSA \& SEVERI 2000). Regarding neotropical teleosts, the paucity of data is mainly due to the difficulty of collecting complete ontogenic series in the wild. For migratory species, as the characid "dourado" Salminus brasiliensis (Cuvier, 1816), the problem is amplified since they spawn in rivers during the rainy season when the floods carry eggs and larvae into usually large floodplains.

Although the dourado Salminus brasiliensis is an important commercial and sport fish, native to the São Franscisco River basin, only recently the first account of its larval ontogeny was published. Thanks to the larvae obtained from artificial propagation, SATO et al. (1997c) have shown that they presented a very fast initial development with the yolk sac been consumed within two days or less. They also confirmed earlier findings of MORAIS FILHO \& SCHUBART (1955) who described a similar adhesive organ on the larval head of Salminus maxillosus, from the Paraná River Basin, which functions as a holding device to the water surface.

1) Programa de Pós-graduação em Zoologia de Vertebrados, Pontifícia Universidade Católica de Minas Gerais. Caixa Postal 2686, 30535-610 Belo Horizonte, Minas Gerais, Brasil.

Revta bras. Zool. 19 (1): $163-171,2002$ 
In the present paper, new data are added such as pattern of skin and retinal pigmentation, time of exogenous feeding, and swimming behavior, that are useful for species characterization, and may have practical applications in aquaculture (MEIJIDE \& GUERRERO 2000). The period of study extended from hatching to yolk sac absorption. Swimming behavior during this period was also documented. The term larvae is used here following WOYNAROVICH \& HORVÁTH (1980) encompassing fish whose life period extends from hatching to gaseous bladder filling. This period corresponds to that of preflexion stage (AHLSTROM \& BALL 1954) or protolarva (ARAÚJO-LIMA et al. 1993).

\section{MATERIAL AND METHODS}

The dourado larvae used in this work were obtained through artificial spawning. Immediately after hatching, 240 larvae were placed in each of three plastic tanks, two-liter capacity, and maintained at room temperature of $23-25^{\circ} \mathrm{C}$, without water renewal. The larvae were exposed to a photoperiod of, approximately, $13 \mathrm{~h}$ light: $11 \mathrm{~h}$ dark that corresponded to the natural conditions prevailing at the time the experiment was conducted.

In order to evaluate larval sizes during treatment, the standard length (SL) of 30 larvae from each tank was measured daily after fixation in 10\% formalin solution for $24 \mathrm{~h}$. The SL was obtained with the help of a caliper under a stereomicroscope and indicated the distance from the tip of the head to notochord caudal end. Another batch of 14 larvae from each tank was also collected daily in order to register the ontogenetic events. They were immediately anaesthetized with ether and examined in a stereomicroscope. Additional 12 larvae were also collected daily from each tank for histological analysis, which could help in the identification of developing characters seen during the macroscopic observations. After fixation in Bouin's fluid, they were embedded in glycol methacrilate and the slide sections stained in $1 \%$ acid blue toluidine. Larval swimming behavior, water temperature and the number of dead larvae were also daily recorded.

At the beginning and end of the experiment, the water $\mathrm{pH}$ and electrical conductivity of the tanks were recorded. They remained, respectively, between 7.2-7.7 and 87.4-89.7 $\mu \mathrm{S} . \mathrm{cm}^{-1}$ which were considered adequate for larval development.

\section{RESULTS}

The almost complete yolk sac absorption of the dourado larvae occurred at the end of day 3 post-hatching (ph). Figures 1-3 are composite drawings and figures 4-14 are photomicrographs of larval sections during development. Total larval mortality rate during the experiment was $5.4 \%$.

\section{Ontogenic events}

Day 1 ph (Fig. 1). Larval observations started at $6 \mathrm{~h}$ ph. At this time, the larvae were elongated, transparent and with dendrite chromatophores on the head. Olfactory pits, brain and otic vesicles with two otoliths of different sizes were observed. The round eyes covered with dendrite chromatophores showed initial pigmentation (Fig. 4). A well-developed cutaneous adhesive organ was present at the rostral portion of the head (Fig. 5). Notochord (Fig. 6) and miomeres were 

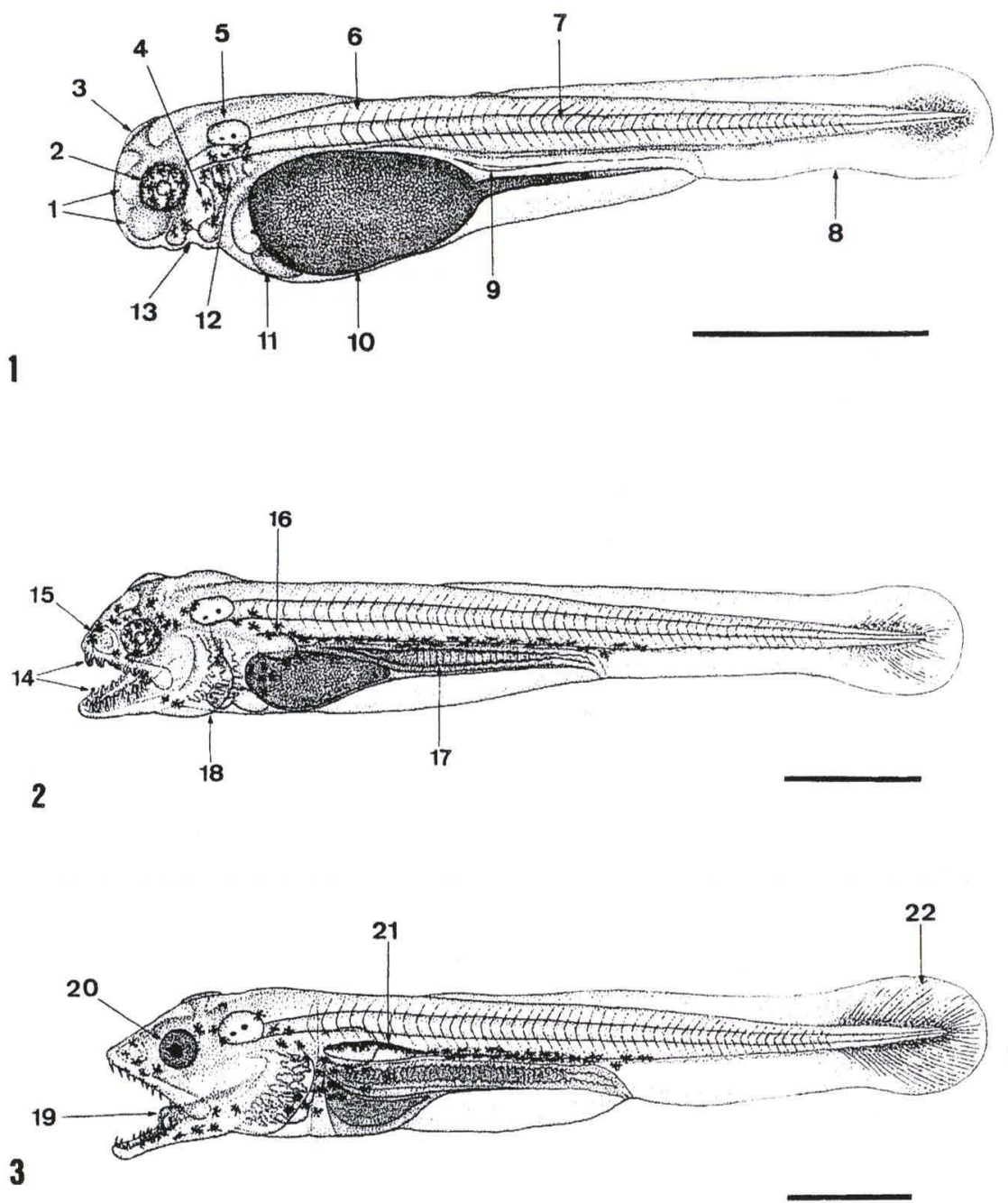

Figs 1-3. Yolk-sac larva of Salminus brasiliensis. (1) Day 1 (6 h ph): (1) brain vesicles, (2) eye, (3) cutaneous adhesive organ, (4) dendrite chromatophores, (5) otic vesicle, (6) miomeres, (7) notochord, (8) embryonic fin, (9) digestive tract, (10) yolk sac, (11) heart, (12) gill arches, (13) mouth depression - standard length $3.7 \mathrm{~mm}$; (2) Day 2 ph: (14) teeth, (15) olfactory pit, (16) pectoral fin, (17) intestine with folded mucosa, (18) operculum -standard length $6.4 \mathrm{~mm}$; (3) Day 3 ph: (19) tongue, (20) pigmented eye, (21) gaseous bladder, (22) caudal fin - standard length $7.0 \mathrm{~mm}$. Bar $1 \mathrm{~mm}$.

evident along the body. Gill arches (Fig. 7) were in differentiation. The digestive tract had reduced lumen (Fig. 8) and the mouth was not opened. The ovoid-shaped yolk sac filled with individualized yolk globules presented a caudal extension. The embryonic fin bordered the caudal half of the body. The paired kidney ducts were evident (Fig. 8). The larvae measured $3.7 \pm 0.14 \mathrm{~mm}$ SL. 

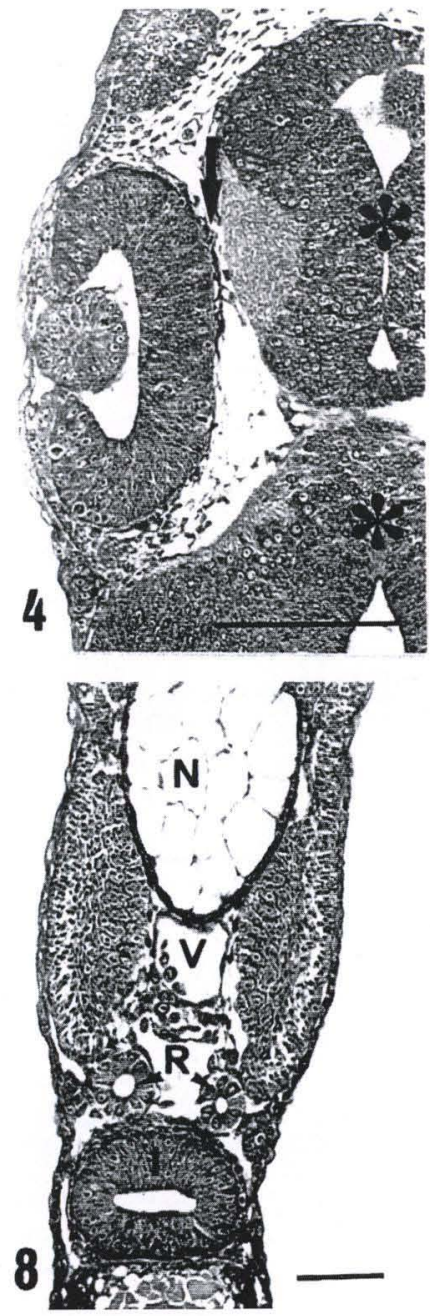
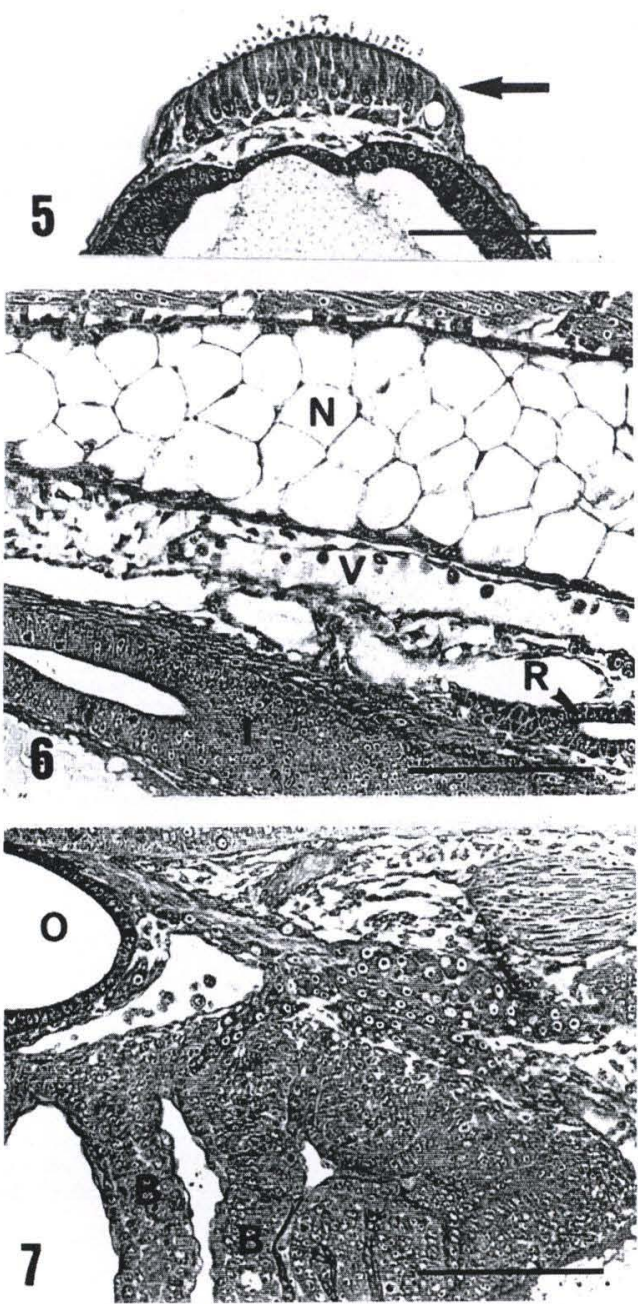

Figs 4-8. Histological sections of yolk-sac larva of Salminus brasiliensis -day 1 ( $6 \mathrm{~h}$ ph, bar 50 $\mu \mathrm{m})$; (4-5) Transverse section of the head showing: (4) the brain vesicles $\left(^{*}\right)$ and epithelial cell layer of the retina at initial pigmentation (arrow), (5) the cutaneous adhesive organ (arrow); (6) longitudinal section through the yolk sac: note the notochord $(N)$, blood vessel (V), caudal kidney (R) and intestine (I); (7) longitudinal section through the gill arches, note part of the otic vesicle $(\mathrm{O})$, and gill arches $(\mathrm{B})$; (8) transverse section of the body, note the notochord $(\mathrm{N})$, blood vessel $(\mathrm{V})$, caudal kidney $(\mathrm{R})$ and intestine $(\mathrm{I})$.

Day 2 ph (Fig. 2). Dendrite chromatophores were also present on the cranial half of the yolk sac, on the coelomic peritoneum and on the skin of the post anal region (Fig. 2). Pigmentation of the retina was uniformly distributed. The mouth was opened bearing a single row of conical teeth on the dentary and on the premaxillary and maxillary bone anlages (Fig. 9). The digestive tract presented 
folded mucosa (Figs 10 and 11). Opercula, gaseous bladder, and pectoral fins appeared on this day. The larvae measured $6.4 \pm 0.32 \mathrm{~mm} \mathrm{SL}$.

Day 3 ph (Fig. 3). The peritoneum was intensively pigmented. The yolk sac was already exhausted in some larvae. The cutaneous adhesive organ was still evident on the head. The opercula now covered the branchial cavity. Although the body pigmentation was more intense than previously, it maintained the same pattern as seen on day $2 \mathrm{ph}$. The epithelial cell layer of the retina was entirely pigmented. The gaseous bladder was inflated (Fig. 12). The lumen of the stomach was evident (Fig. 13). Goblet cells were observed in the intestinal mucosa (Fig. 14). The larvae measured $7.0 \pm 0.35 \mathrm{~mm} \mathrm{SL}$.

\section{Swimming behavior}

Day 1 ph. The larvae, when resting in the tank bottom, laid on their sides forming groups of 3-15 individuals arranged in circle with the head directed to the center. Occasionally, they moved vertically or inclined towards the water surface and then passively fell to the bottom.

Day 2 ph. The larvae were now then able to swim horizontally. When resting in the tank bottom they were still arranged in circle, although in smaller groups of 3-6 individuals. From this day on they were able to hang in the water surface through the cutaneous adhesive organ.

Day 3 ph. On this day, no more larval group arrangement on tank bottom was recorded. When resting, they were laying laterally or ventrally. Cannibalism was first observed.

\section{DISCUSSION}

\section{Chromatophore morphology}

A detailed description of fish larvae chromatophores is important since they are a taxonomic character used for identification (SIMON \& VONDRUSKA 1991; MEIJIDE \& GUERRERO 2000). Dourado larvae showed exclusively dendrite chromatophores which appeared initially on the head skin and then spread caudally on the larval body, yolk sac and peritoneum. This type of chromatophore has also been described in other characiform larvae (ARAÚJO-LIMA et al. 1993; NASCIMENTO \& ARAÚJO-LIMA 1993; SANTOS \& GODINHO 1996a,b) and in other fish groups (SANTOS \& GODINHO 1994).

\section{Cutaneous adhesive organ}

Adhesive organs have been reported in various characiform (Astyanax: AZEVEDO \& VIEIRA 1938; Brycon lundii: SATO et al. 1997b; Salminus maxillosus: MORAIS FILHO \& SCHUBART 1955; Hoplias: IHERING \& AZEVEDO 1936b and AZEVEDO et al. 1938; Steindachnerina elegans (= Curimata elegans): AZEVEDO et al. 1938, AZEVEDO \& VIEIRA 1939 and SATO et al. 1997a) and in the perciform Cichla ocellaris (FONTENELE 1950), Geophagus brasiliensis (AZEVEDO et al. 1938) and Cichlasoma dimerus (MEIJIDE \& GUERRERo 2000). In Salminus brasiliensis (present study), the organ was still well evident on day $3 \mathrm{ph}$, indicating that it could remain longer on the larvae. It proved to be functional on day $2 \mathrm{ph}$ when the larvae 

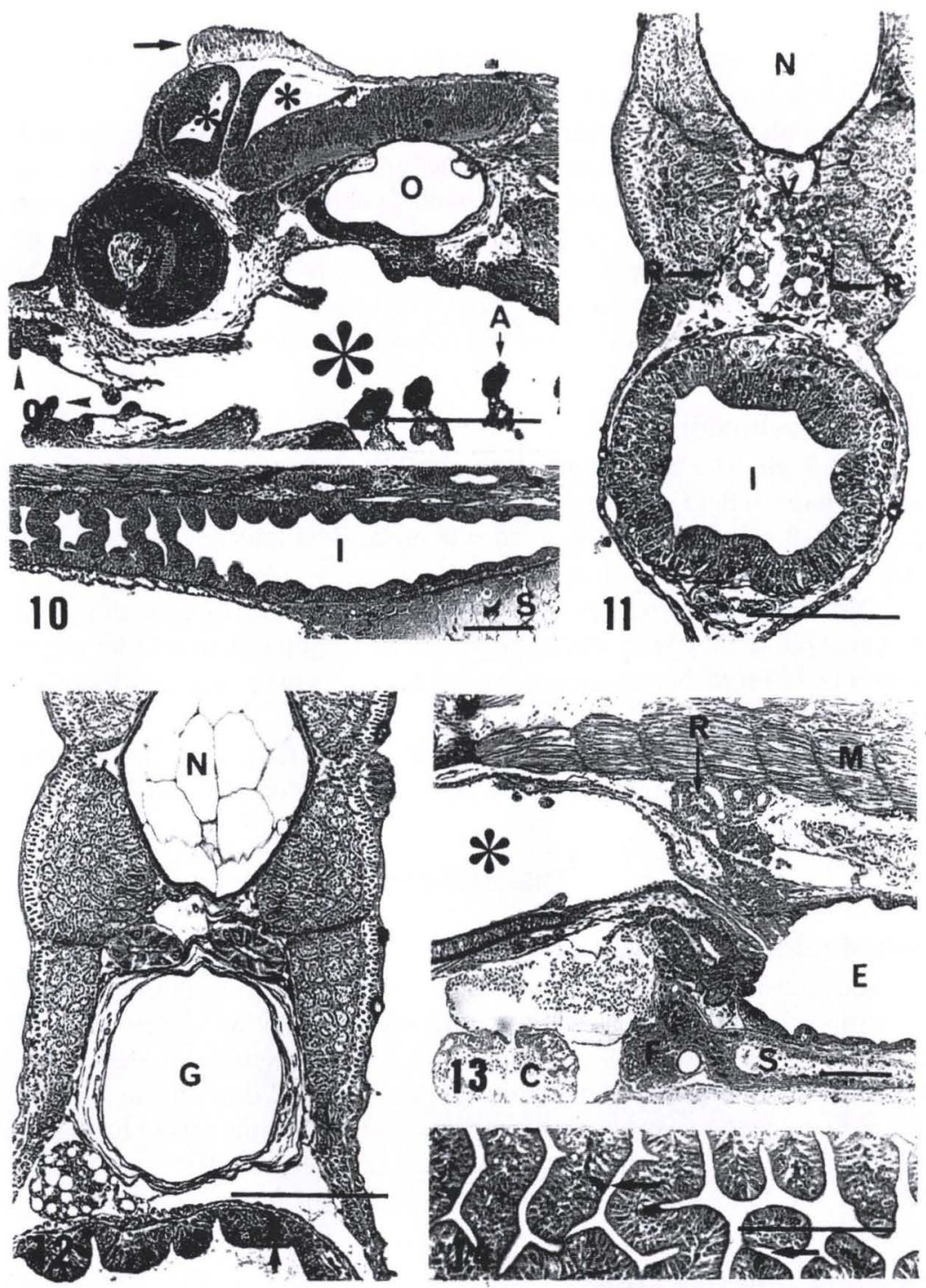

Figs 9-14. Histological sections of yolk-sac larva of Salminus brasiliensis. (9-11) Day 2 ph (bar $50 \mu \mathrm{m}$ ): (9) longitudinal section of the head, note the cutaneous adhesive organ (arrow); brain vesicles (small asterisks), otic vesicle $(\mathrm{O})$, teeth (head arrows), gill arch (A) and gill cavity (large asterisk); (10) longitudinal section through the yolk sac (S) and intestine (I); (11) transverse section of the body: note the notochord $(\mathrm{N})$, blood vessel $(\mathrm{V})$, caudal kidney $(\mathrm{R})$ and intestine (I); (12-14) day $3 \mathrm{ph}$ (bar $50 \mu \mathrm{m})$ : (12) Transverse section through the notochord (N), gaseous bladder (G) and intestine with goblet cell (arrow); (13) longitudinal section through miomeres $(M)$, cranial kidney $(R)$, gill cavity $\left({ }^{*}\right)$, stomach $(E)$, heart $(C)$, liver $(F)$ and yolk sac at the end of the absorption period (S); (14) longitudinal section through the intestine, note the folded mucosa with goblet cells (arrows). 
started to hang in the water surface. Depending on the reproductive strategy adopted by the fish species, the organ may be adapted to perform different functions. In sedentary species, such as $C$. dimerus, the organ helps prevent dispersion by water currents and facilitates parental care (MEIJIDE \& GUERRERO 2000). However, in migratory species, such as $S$. brasiliensis, it may play an important role in larval dispersion by adhering to the river surface water.

\section{Yolk sac duration}

The absorption period of the yolk sac is vital to fish larvae since the digestive system is still under differentiation. The absorption period varies in neotropical larvae from 2.5 days, in Rhamdia quelen (IHERING \& AZEVEDO 1936a), to 8.8 days in Hoplias malabaricus (MATKOVIC \& PISANÓ 1989). The dourado yolk sac remained until day 3 ph thus indicating that it may be included in the group of species with short yolk sac duration.

\section{Exogenous feeding and retinal pigmentation}

Mouth opening and eye pigmentation are events that appear almost simultaneously since they are both closely related to first exogenous feeding (LASKER $e t$ al. 1970). In the dourado, retinal pigmentation started on day $1 \mathrm{ph}$ and was completed on day $3 \mathrm{ph}$ whereas the mouth opened on day $2 \mathrm{ph}$. Pseudoplatystoma coruscans (SANTOS \& GODINHO 1994) and S. brasiliensis (present study) have their buccal apparatus organized by the day $2 \mathrm{ph}$ indicating their ability to apprehend exogenous food items at this early age; on the contrary, Piaractus mesopotamicus (SANTOS \& GODINHO 1996a) and Leporinus elongatus (SANTOS \& GODINHO 1996b) apparently would be able to ingest exogenous items only at day 4 ph. Pattern and age of retina pigmentation vary among neotropical species. The retinal pigmentation of Leporinus elongatus (SANTOS \& GODINHO 1996b) and S. brasiliensis (present study) appears uniformly distributed in the retina whereas in Pseudoplatystoma coruscans the pigmentation spreads from the center to the periphery of the retina (SANTOS \& GODINHO 1994). The retina of $S$. brasiliensis apparently is in process of pigmentation starting at an earlier age than that of the neotropical Pseudoplatystoma coruscans (SANTOS \& GODINHO 1994) and Leporinus elongatus (SANTOS \& GODINHO 1996b) in which only at day 2 ph the first signs of pigmentation were registered.

\section{Swimming behavior}

Immediately after hatching, the larvae remained most of the time resting on their sides. This was probably due to the yolk sac weight and the absence of functional gaseous bladder and pectoral fins. Later, the larvae showed active vertical and horizontal movements and headed passively towards the tank bottom. These observations agree with those made by AZEVEDO et al. (1938), AZEVEDO \& VIEIRA (1939) and AZEVEDo \& GOMES (1942) for other neotropical fish larvae.

ACKNOWLEDGMENTS. We thank the Conselho Nacional de Desenvolvimento Científico e Tecnológico - CNPq (Grant \# 403354/90-0) for partial support), Y. Sato from Três Marias Hatchery Station - CODEVASF for larval supply, R. Miranda for technical assistance, and the two anonymous referees for their criticism and suggestions. 


\section{REFERENCES}

Ahlstrom, E.H. \& O.P. BALl. 1954. Description of eggs and larvae of mackerel (Trachurus symmetricus) and distribution and abundance of larvae in 1950 and 1951. Fish. Bull. U.S. 56: 209-245.

Araúso-Lima, C.A.R.M.; A.L. Kirovsky \& A.G. MARCA. 1993. As larvas dos pacus, Mylossoma spp. (Teleostei; Characidae), da Amazônia Central. Rev. Brasil. Biol. 53 (3): 591-600.

AzEvedo, P. \& A.L. Gomes. 1942. Contribuição ao estudo da biologia da traíra Hoplias malabaricus (Bloch, 1794). Bol. Ind. Anim., São Paulo, 5 (4): 15-64.

AzEVEDo, P. \& B.B. VIEIRA. 1938. Contribuição para o catálogo biológico dos peixes fluviais do nordeste do Brasil. II. Piabas. Bol. Insp. Fed. Obr. Cont. Secas, Rio de Janeiro, 10 (1): 71-75.

- 1939. Contribuição para o catálogo biológico dos peixes fluviais do nordeste do Brasil. III. Saguiru. Bol. Insp. Fed. Obras Contra Seca, Rio de Janeiro, 11 (2): 181-184.

Azevedo, P.; M. Vianna-Dias \& B.B. Vieira. 1938. Biologia do saguirú (Characidae, Curimatidae). Mem. Inst. Osw. Cruz 33 (4): 481-553.

FontENELE, O. 1950. Contribuição para o conhecimento da biologia dos tucunarés (Actinopterygii, Cichlidae), em cativeiro. Aparelho de reprodução. Hábitos de desova e incubação. Rev. Brasil. Biol. 10 (4): 503-519.

IHERING, R. \& P. Azevedo. 1936a. As piabas dos açudes nordestinos (Characidae, Tetragonopterinae). Arch. Inst. Biol., São Paulo, 7 (9): 75-105.

-1936b. A desova e a hipofisação dos peixes. Evolução de dois Nemotognathas. Arch. Inst. Biol., São Paulo, 7 (9): 107-117.

Lasker, R.; H.M. Feder; G.H. Theilacher \& R.C. May. 1970. Feeding, growth and survival of Engraulis mordax larvae reared in the laboratory. Mar. Biol. 5: 345-353.

Matkovic, M. \& A. Pisanó. 1989. Estudio macro y microscopio del desarrollo de Hoplias m. malabaricus (Pisces, Erythrinidae). I: fase larval. Rev. Brasil. Biol. 49 (2): 553-569.

MEIIIE, F.J. \& G.A. GuERRERo. 2000. Embryonic and larval development of a substrate-brooding cichlid Cichlasoma dimerus (Heckel, 1940) under laboratory conditions. Jour. Zool. London 252: 481-493.

Morais Filho, M.B. \& O. SchubarT. 1955. Contribuição ao estudo do dourado (Salminus maxillosus Val.). São Paulo, Ministério da Agricultura, Divisão de Caça e Pesca, 131p.

NAscimento, F.L. \& C.A.R.M. ARAúJo-LimA. 1993. Descrição das larvas de Psectrogaster amazonica e Potamorhina altamazonica (Curimatidae, Pisces) da Amazônia Central. Acta Amazonica 23 (4): 457-472.

Santos, J.E. \& H.P. Godinho. 1994. Morfogênese e comportamentos larvais do surubim (Pseudoplatystoma coruscans Agassis, 1829) sob condições experimentais. Arq. Bras. Med. Vet. Zootec., Belo Horizonte, 40 (2): 139-147.

- 1996a. Ontogênese e comportamento natatório das larvas do pacu (Piaractus mesopotamicus Homberg, 1887) mantidas experimentalmente em três regimes de fotoperíodo. BIOS 4 (4): 11-16.

- 1996b. Larval ontogeny and swimming behaviour of the leporin fish Leporinus elongatus (Valenciennes, 1874) under experimental conditions. Arq. Bras. Med. Vet. Zootec., Belo Horizonte, 48 (Supl. 1): 109-116.

Sato, Y.; E.V. Sampaio; H.P. Godinho; N. Fenerich-Verani \& J.R. Verani. 1997a. Biologia reprodutiva do saguiru Steindachnerina elegans (= Curimata elegans Steindachner, 1875) (Pisces: Curimatidae) submetido à hipofisação. BIOS 5 (5): 37-41.

Sato, Y.; N. Fenerich-Verani; H.P. Godinho; J.R. Verani \& L.J.S. Vieira. 1997b. Reprodução induzida do matrinchã Brycon lundii Reinhardt, 1877, da bacia do rio São Francisco. In: Anais VIII Seminário Regional de Ecologia, São Carlos, 7, p. 353-359. 
Sato, Y.; N. Fenerich-Verani; J.R. Verani; H.P. Godinho \& L.J.S. Vieira. 1997c. Reprodução artificial do dourado Salminus brasiliensis (Pisces: Characidae) da bacia do rio São Francisco. Rev. Bras. Reprod. Anim. 21 (3): 113-116.

Simon, T.P. \& J.T. Vondruska. 1991. Larval identification of the ruffe, Gymnocephalus cernus (Linnaeus) (Percidae: Percini), in the St. Louis River Estuary, Lake Superior drainage basin, Minnesota. Can. Jour. Zool. 69: 436-442.

SousA, W.T.Z. \& W. SEveri. 2000. Desenvolvimento larval inicial de Helostoma temminckii Cuvier \& Valenciennes (Helostomatidae, Perciformes). Revta bras. Zool. 17 (3): 637-644

Woynarovich, E. \& L. HorvátH. 1980. The artificial propagation of warm-water finfishes - a manual for extension. Rome, FAO Fish. Tech. Pap. 201, 83p.

Recebido em 28.XII.2000; aceito em 28.I.2002. 